\title{
THE EFFECT OF HYPNOTHERAPY ON ALLEVIATING ANXIETY AMONG WOMEN PREPARING FOR CAESAREAN SECTION
}

\author{
Rizka Innayatun Mubarokah'), Hanung Prasetya'), \\ Supriyadi Hari Respati3) \\ ${ }^{1)}$ Masters Program in Public Health, Universitas Sebelas Maret \\ ${ }^{2}$ School of Health Polytechnics, Ministry of Health, Surakarta \\ 3)Department of Obstetrics and Gynecology, Dr. Moewardi Hospital, Surakarta
}

\begin{abstract}
Background: A perioperative period is a stressful event that triggers specific emotional, cognitive, and physiological responses. To overcome preoperative anxiety among women who prepare for cesarean section, various psychological techniques are used. Hypnosis is a method which may empower the mind to respond to stress more positively. The purpose of this study was to examine the effect of hypnotherapy on alleviating anxiety among women preparing for cesarean section.

Subjects and Method: A randomized control trial was carried out at Karanganyar and PKU Muhammadiyah hospitals, Central Java, from July to August 2019. A sample of 60 pregnant mothers with section cesarean was selected purposively. The dependent variable was hypnotherapy. The independent variables were maternal anxiety. Anxiety was measured by Hamilton Anxiety Rating Scale (HARS). Means of HARS score between groups were compared by independent t test.

Results: Mean of anxiety in the hypnotherapy group was lower (Mean=14.17; SD= 4.36) than the control group (Mean=19.93; $\mathrm{SD}=6.02$ ), and it was statistically significant $(\mathrm{p}<0.001)$.

Conclusion: Hypnotherapy is effective to alleviate anxiety in pregnant women preparing for cesarean section.
\end{abstract}

Keywords: anxiety, cesarean section, hypnotherapy, pregnant women

\section{Correspondence:}

Rizka Innayatun Mubarokah. Masters Program in Public Health, Universitas Sebelas Maret, Surakarta. Jl. Ir. Sutami 36 A, Surakarta 57126, Central Java. Email: rizka.inn@gmail.com. Mobile: 082240337404.

The $6^{\text {th }}$ International Conference on Public Health

Best Western Premier Hotel, Solo, Indonesia, October 23-24, 2019 | 209

https://doi.org/10.26911/the6thicph.03.67 